\title{
Particulate organic nitrates observed in an oil and natural gas production region during wintertime
}

\author{
L. Lee ${ }^{1}$, P. J. Wooldridge ${ }^{1}$, J. deGouw ${ }^{2}$, S. S. Brown ${ }^{2}$, T. S. Bates ${ }^{3}$, P. K. Quinn ${ }^{4}$, and R. C. Cohen ${ }^{1,5}$ \\ ${ }^{1}$ Department of Chemistry, University of California, Berkeley, CA, USA \\ ${ }^{2}$ Chemical Science Division, Earth System Research Laboratory, National Oceanic \& Atmospheric Administration, \\ Boulder, CO, USA \\ ${ }^{3}$ Joint Institute for the Study of the Atmosphere and Ocean, University of Washington, Seattle, WA, USA \\ ${ }^{4}$ Pacific Marine Environment Laboratory, National Oceanic \& Atmospheric Administration, Seattle, WA, USA \\ ${ }^{5}$ Department of Earth and Planetary Sciences, University of California, Berkeley, CA, USA \\ Correspondence to: R. C. Cohen (rccohen@berkeley.edu)
}

Received: 24 February 2015 - Published in Atmos. Chem. Phys. Discuss.: 13 April 2015

Revised: 15 July 2015 - Accepted: 27 July 2015 - Published: 21 August 2015

\begin{abstract}
Organic nitrates in both gas and condensed (aerosol) phases were measured during the Uintah Basin Winter Ozone Study from January to February in 2012. A high degree of correlation between total aerosol volume at diameters less than $500 \mathrm{~nm}$ and the particulate organic nitrate concentration indicates that organic nitrates are a consistent, if not dominant, fraction of fine aerosol mass. In contrast, a similar correlation with sub- $2.5 \mu \mathrm{m}$ aerosol volume is weaker. The $\mathrm{C}: \mathrm{N}$ atomic ratio inferred from field measurements of $\mathrm{PM}_{2.5}$ and particulate organic nitrate is $34: 1$. Calculations constrained by the observations indicate that both condensation of gas-phase nitrates and heterogeneous reactions of $\mathrm{NO}_{3} / \mathrm{N}_{2} \mathrm{O}_{5}$ are responsible for introducing organic nitrate functionality into the aerosol and that the source molecules are alkanes. Extrapolating the results to urban aerosol suggests organic nitrate production from alkanes may be a major secondary organic aerosol source.
\end{abstract}

\section{Introduction}

Submicron-sized aerosols affect the global radiative balance directly as a result of variation in their optical properties and indirectly via their effect on clouds. They modulate atmospheric composition by scavenging gas-phase material, including oxidants. The aerosols impact visibility and public health (Hallquist et al., 2009; Went, 1960; Kleinman et al., 1995). Observations have shown that submicron-sized aerosols typically contain $\sim 50 \%$ organic material by mass (Zhang et al., 2007), and the sources of these organic aerosols have been the subject of considerable debate (Bahreini et al., 2012; Gentner et al., 2012; Shilling et al., 2013; Worton et al., 2013). Field observations have found organic aerosol in urban areas to correlate with anthropogenic emissions, and that they are formed in the atmosphere through chemical reactions of gaseous precursors (Hallquist et al., 2009). However, it has also been shown that urban organic aerosol contains significant amount of carbon that is "modern" (Lewis et al., 2004; Szidat et al., 2004; Zhang et al., 2013), i.e., from a biological source, such as biogenic emissions or biomass burning. It remains challenging to explain secondary organic aerosol (SOA) produced from modern carbon but controlled by anthropogenic emissions (Weber et al., 2007). Nitrogen oxides $\left(\mathrm{NO}_{x}\right)$ are possible candidates for modulating aerosol formation as they are primarily anthropogenic, and so an aerosol formation pathway mediated by $\mathrm{NO}_{x}$ may explain this seemingly counterintuitive phenomenon in terms of radiocarbon age. One potential tracer for this process is organic nitrates in aerosol.

Recently, methods to identify organic nitrate in ambient aerosol have become available. Observations in chamber studies of the $\mathrm{NO}^{+} / \mathrm{NO}_{2}^{+}$peaks in aerosol mass spectrometer measurements (Rollins et al., 2010a, 2009; Farmer et al., 2010), by Fourier transform infrared spectroscopy (FTIR) of ambient aerosol (Day et al., 2010; Mylonas et al., 1991; Garnes and Allen, 2002) and by thermal dissociation-laser- 
induced fluorescence (TD-LIF) of ambient aerosol (Rollins et al., 2012, 2013, 2010b), indicate that organic nitrates in ambient aerosol are observable, and that there are mechanisms to produce them in significant yields from common organic precursors. For example, in Bakersfield, California, during summer, Rollins et al. (2012) found that aerosolbound organic nitrate production contributed to as much as $30 \%$ of the aerosol growth rate at night, with the nitrooxy group representing $8.4 \%$ of the growth mass.

Recent studies of organic matter in ambient aerosol have focused on anthropogenic emissions of gasoline, diesel (Gordon et al., 2013; Jathar et al., 2013; Gentner et al., 2012; Bahreini et al., 2012), motor oil (Worton et al., 2014) and biogenic VOCs (Brown et al., 2009; Paulot et al., 2009; Froyd et al., 2010) as precursors. For long-chain aliphatics, laboratory experiments and simulations have demonstrated substantial contribution of organic nitrates in the resulting particulate matter (Jordan et al., 2008; Lim and Ziemann, 2009; Matsunaga and Ziemann, 2010), but there exist few field observations capable of assessing whether these mechanisms are representative of the ambient processes. Here we describe observations of organic nitrate aerosol observed in the Uintah Basin, Utah, during winter 2012. The measurement site is heavily influenced by oil and gas drilling operations and has negligible input of biogenic emissions, providing an excellent opportunity to explore the role of organic nitrates formed from aliphatic compounds in the production of ambient aerosol.

\section{Methods}

Observations of $\mathrm{NO}_{2}$, total organic nitrates and particulate organic nitrates ( $p \Sigma$ ANs) were made as part of the Uintah Basin Winter Ozone Study (UBWOS) in January and February of 2012. The instruments were installed on a $19 \mathrm{~m}$ tower located on an operational oil and gas well pad containing a wellhead for water injection with a nearby unpaved access road. The measurement site $\left(40.14370^{\circ} \mathrm{N}, 109.46718^{\circ} \mathrm{W}\right)$ is approximately 30 miles $(\sim 50 \mathrm{~km})$ south of Vernal, the nearest town in Utah. The aerosol measurements that are the focus of this manuscript were made from inlets $9 \mathrm{~m}$ above the ground.

$\mathrm{NO}_{2}$, total organic nitrates and $p \Sigma \mathrm{ANs}$ were measured by TD-LIF with coupling to an inlet denuder as described in Rollins et al. (2010). TD-LIF is described in detail elsewhere (Day et al., 2002; Thornton et al., 2000). Briefly, in these experiments a CW $408 \mathrm{~nm}$ solid-state diode laser (Power Technology Inc., LDCU12/7639) was used to excite $\mathrm{NO}_{2}$ molecules. The laser light was directed sequentially into three multi-pass white cells and total fluorescence due to $\mathrm{NO}_{2}$ at wavelengths longer than $700 \mathrm{~nm}$ was detected using a red-sensitive photomultiplier tube (Hamamatsu H7421-50) behind dielectric filters that set the transmission window. The cell pressure was maintained at 3 Torr.
Simultaneous detection of organic nitrate species was accomplished by quantitative conversion of alkyl nitrate $\left(-\mathrm{ONO}_{2}\right)$ and peroxy nitrate $\left(-\mathrm{OONO}_{2}\right)$ moiety to $\mathrm{NO}_{2}$ molecules through thermal decomposition at $17 \mathrm{~ms}$ residence time at $380^{\circ} \mathrm{C}$ in a $0.25 \mathrm{in}$. OD quartz tube. The sampled air contained both gas- and aerosol-phase organic nitrates which, upon passing through the thermal dissociation (TD) oven, were converted into an excess $\mathrm{NO}_{2}$ signal compared to the ambient $\mathrm{NO}_{2}$ concentration monitored simultaneously in an unheated channel. To distinguish the particulate-phase component, an activated charcoal multi-channel denuder of $10 \mathrm{~cm}$ in length (MAST Carbon Inc.) was placed ahead of another $380^{\circ} \mathrm{C}$ thermal dissociation oven to remove the gasphase organics (Rollins et al., 2010b) as well as $\mathrm{NO}_{2}$ so that only aerosol-phase components remained. The particle transmission efficiency of the denuder was calculated to be $60 \%$ for $20 \mathrm{~nm}$ diameter particles and over $90 \%$ for particles larger than $70 \mathrm{~nm}$ diameter, ensuring detection of the vast majority of aerosol mass. To reduce intake of dust, a $2.5 \mu \mathrm{m}$ cyclone was placed on the main inlet with a bypass pump maintaining the necessary total flow rate of $5 \mathrm{~L} \mathrm{~min}^{-1}$. In addition to these TD-LIF measurements, $\mathrm{N}_{2} \mathrm{O}_{5}$ (Wagner et al., 2011), peroxy acetyl nitrate (PAN) (Williams et al., 2000) and $\mathrm{ClNO}_{2}$ (Roberts et al., 2009) were independently measured. Total alkyl nitrate $(\Sigma \mathrm{AN})$ is defined as the measured TD-LIF signal at $380^{\circ} \mathrm{C}$, corrected for ozone effects (Lee et al., 2014) and with $\mathrm{NO}_{2}, \mathrm{~N}_{2} \mathrm{O}_{5}$, PAN and $\mathrm{ClNO}_{2}$ subtracted. The particle organic nitrate observations require no correction as gas-phase molecules are scrubbed by the denuder. We expect alkyl nitrates to be the dominant component of the particulate organic nitrate signal observed, because the peroxy nitrate concentration and the concentration of its precursors are much lower than the corresponding alkyl nitrates.

The TD-LIF instrument was calibrated hourly using locally generated zero air mixed with an $\mathrm{NO}_{2}$ standard to give five different concentration levels, spanning a range from 0 to $20 \mathrm{ppb}$. The instrument zero was monitored twice per hour. Concentration data were reported to the NOAA archive (http://esrl.noaa.gov/csd/groups/csd7/measurements/ 2012ubwos/) at a time resolution of $1 \mathrm{~min}$, averaged from $1 \mathrm{~Hz}$ raw data. The detection limit for the instrument at $1 \mathrm{~min}$ averaging time was $24 \mathrm{ppt}$ for $\mathrm{NO}_{2}$ and particulate nitrate and $34 \mathrm{ppt}$ for total organic nitrate, defined as the $1 \sigma$ value of the noise. The charcoal denuder was occasionally checked for saturation by introducing the calibration $\mathrm{NO}_{2}$ gas mixture before, rather than after, the denuder section in a calibration routine, and no $\mathrm{NO}_{2}$ breakthrough was observed.

Colocated aerosol instrumentations include measurements of the particle size distribution from 10 to $500 \mathrm{~nm}$ diameter range using a scanning mobility particle sizer (SMPS, TSI Inc.), from 0.7 to $10 \mu \mathrm{m}$ diameter range using an aerodynamic particle sizer (APS, TSI Inc.), and an aerosol mass spectrometer (AMS, Aerodyne Inc.). Sub-2.5 $\mu \mathrm{m}$ aerosol filter samples were collected twice daily, one covering daytime and the other covering nighttime. Properties derived from 

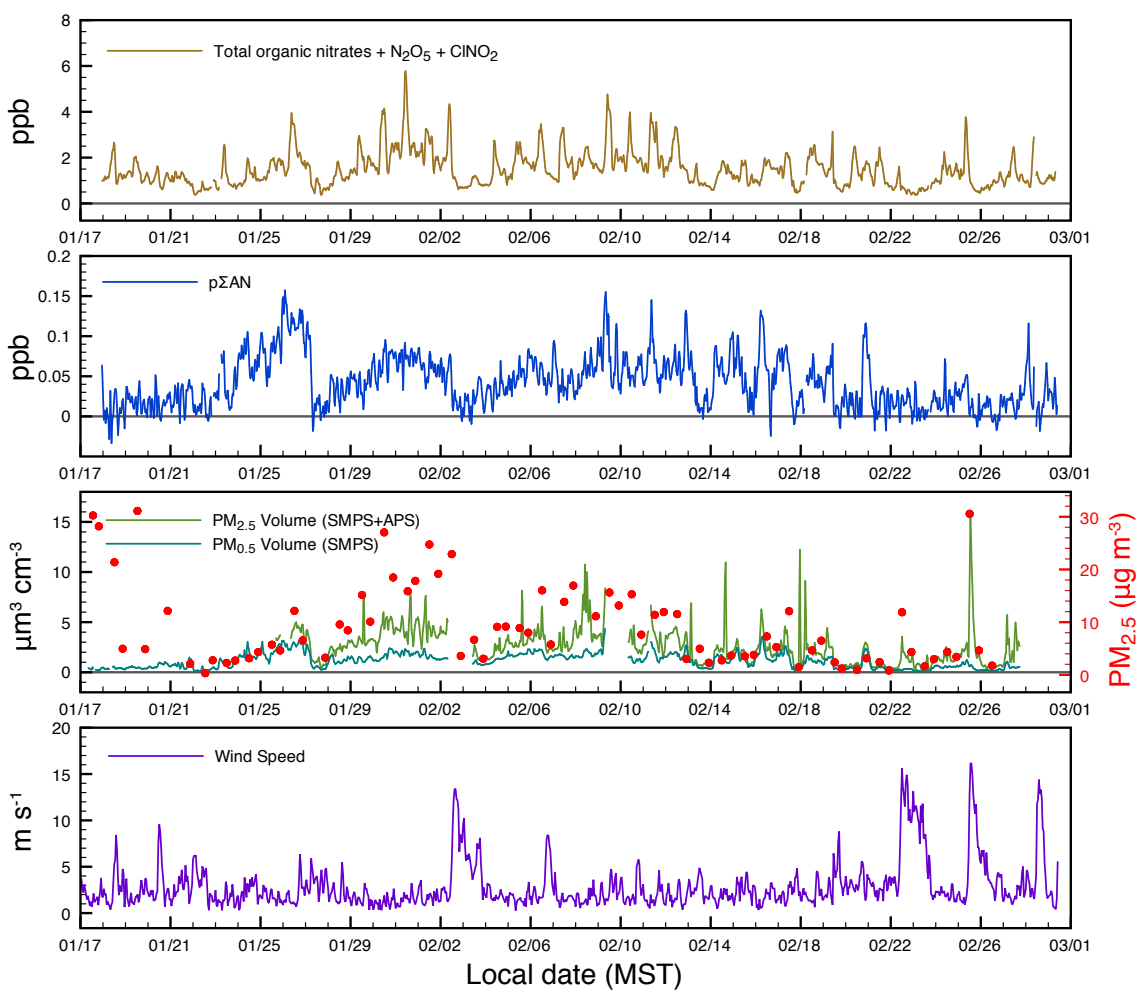

Figure 1. Hourly time series from measurements of total organic nitrates plus $\mathrm{N}_{2} \mathrm{O}_{5}$ and $\mathrm{ClNO}_{2}$, particulate organic nitrate ( $p \Sigma \mathrm{AN}$ ), and total aerosol volume measured by SMPS and APS with filter-sampled $\mathrm{PM}_{2.5}$ mass (red dots, secondary axis) and local wind speed.

these filter samples include total aerosol mass, total organic carbon (OC), total elemental carbon (EC) and cation concentrations (ion chromatography). A particle-into-liquid sampler (PILS) was colocated with the filter sampler. Meteorological conditions were recorded at the top of the $19 \mathrm{~m}$ tower, including wind direction, wind speed, temperature, pressure and relative humidity. Gas-phase measurements used in this analysis include gas chromatography with mass selective detector (GC-MS) and proton transfer mass spectrometry (PTR-MS) for VOC speciation, cavity ring-down spectroscopy (CRDS) for $\mathrm{N}_{2} \mathrm{O}_{5}$ and $\mathrm{NO}_{3}$, chemical ionization mass spectrometry (CIMS) for $\mathrm{ClNO}_{2}$, and gas chromatography with electron capture detection (GC-ECD) for PAN. (For a comprehensive list, see: http://esrl.noaa.gov/csd/groups/csd7/measurements/ 2012ubwos/instruments.html.)

\section{Observations}

The concentration of total organic nitrates (including the contribution from $\mathrm{ClNO}_{2}$ and $\mathrm{N}_{2} \mathrm{O}_{5}$ ) and particulate nitrates ( $p \Sigma \mathrm{ANs})$ are shown in Fig. 1. After correcting for PAN, $\mathrm{ClNO}_{2}$ and $\mathrm{N}_{2} \mathrm{O}_{5}, \Sigma$ ANs account for an afternoon peak of $40 \% \mathrm{NO}_{y}$ and exhibit a strong diurnal pattern, reaching a median value of $2.2 \mathrm{ppb}$ at local noon as shown in Fig. 2. At night high concentrations of $\mathrm{N}_{2} \mathrm{O}_{5}$ and $\mathrm{ClNO}_{2}$ $(\sim 0.6$ ppb combined) were present and $\Sigma$ ANs decreased to approximately $300 \mathrm{ppt}$. PAN was about $250 \mathrm{ppt}$ at night, increasing to $400 \mathrm{ppt}$ in the late afternoon. A median value of 45 ppt $p \Sigma$ ANs was observed with a peak value around $150 \mathrm{ppt}$ (Fig. 1). The level of $p \Sigma \mathrm{AN}$ varied more slowly than $\Sigma$ ANs, except at times of pristine air intrusion, during which its concentration decreased promptly. From a multi-day perspective, $p \Sigma$ ANs were observed to accumulate during stagnant periods, as did long-lived trace gases including VOCs, $\mathrm{NO}_{2}$ and $\Sigma$ ANs. Local VOC composition consisted predominately of alkanes, which accounted for $\sim 77 \%$ of total $\mathrm{OH}$ reactivity $\left(6.5 \mathrm{~s}^{-1}\right)$ due to VOC. Alkenes, alkynes and aromatics accounted for only 2.3, 0.2 and $8.9 \%$ of $\mathrm{OH}$ reactivity, respectively.

$p \Sigma \mathrm{AN}$ was correlated with other aerosol measurements, the strongest of which $\left(R^{2}=0.72\right)$ was with aerosol volume at diameters below $500 \mathrm{~nm}$ (Fig. 3). In contrast, the correlation with total aerosol volume up to $2.5 \mu \mathrm{m}$ particle diameter is weaker $\left(R^{2}=0.23\right)$. We believe this is due to the presence of mineral dust in the larger size fraction. The source of this dust is likely exposed dry soil on the numerous unpaved roads in the surrounding area. Correlations between $p \Sigma A N$ and gas-phase species such as propane $\left(R^{2}=0.15\right)$ and $\mathrm{NO}_{2}$ $\left(R^{2}=0.1\right)$ are weak. 

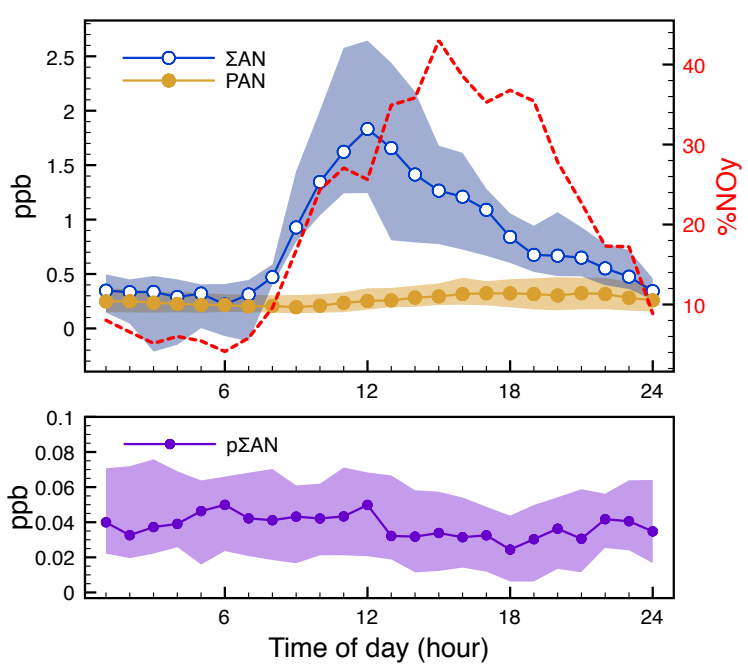

Figure 2. Average mixing ratios of total alkyl nitrate ( $\Sigma \mathrm{AN}$, blue), PAN (yellow), $\left(\Sigma \mathrm{AN} / \mathrm{NO}_{y}\right) \times 100 \%$ (red dashed) and $p \Sigma \mathrm{AN}$ (purple) vs. time of day. Interquartile range is shaded.

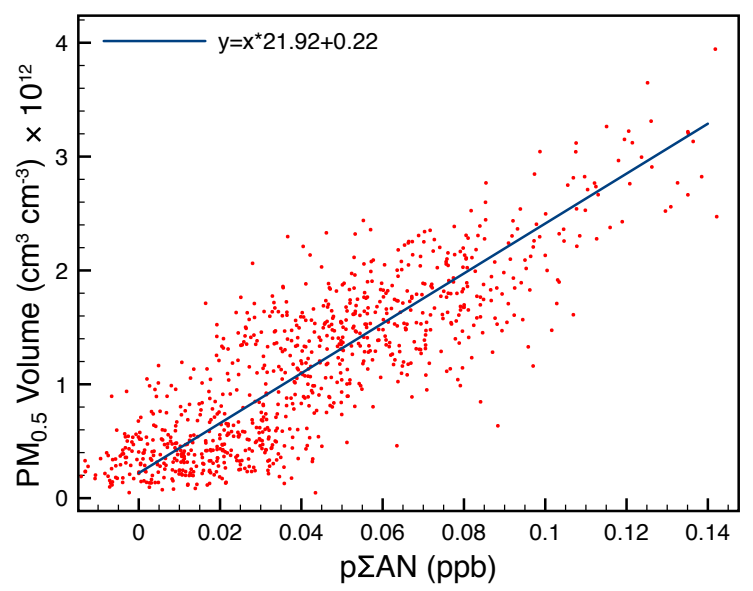

Figure 3. Correlation of $\mathrm{PM}_{0.5}$ volume measured by SMPS to particulate organic nitrate concentration $\left(R^{2}=0.72\right)$.

\section{Discussion}

\subsection{Aerosol composition inferred from observations}

The inorganic components observed in aerosol during UBWOS consist of mineral dust, salts and elemental carbon. Since $p \Sigma A N$ data represent condensed-phase organic nitrooxy groups, the strong correlation of $p \Sigma$ ANs concentration with $\mathrm{PM}_{0.5}$ volume is suggestive of the existence of both a significant organic component and a persistent nitrooxy functionality in this size range. Complementary evidence for this observation is obtained by correlating the concentration of aerosol $\mathrm{Ca}^{2+}$, typically found in minerals, with the total aerosol volume at diameters between $500 \mathrm{~nm}$ and $2.5 \mu \mathrm{m}$. The resulting high correlation $\left(R^{2}=0.78\right)$ is in contrast to the one obtained for $\mathrm{Ca}^{2+}$ with the $\mathrm{PM}_{0.5}$ volume
$\left(R^{2}=0.03\right)$, again lending support to the assumption that the organic particles dominate the particle size range under $500 \mathrm{~nm}$ while inorganic components dominate the size range from $500 \mathrm{~nm}$ to $2.5 \mu \mathrm{m}$.

To obtain a quantitative estimate of organic/inorganic mass in $\mathrm{PM}_{2.5}$, linear decomposition of aerosol specific volume was used (Appendix A). The specific volume was calculated as the ratio of $\mathrm{PM}_{2.5}$ aerosol volume measured by SMPS and APS divided by $\mathrm{PM}_{2.5}$ aerosol mass from impactor filter samples. The use of filter data limits the number of independent estimations to two values daily, one during the day and one during the night. This method assumes that inorganic and organic components have distinctive values in density, and they form external mixture in the aerosol phase. The resulting equation relating the observed $\mathrm{PM}_{2.5}$ specific volume $(\widetilde{v})$ to aerosol organic nitrate group mass fraction $\left(f_{\mathrm{ONO}_{2}}\right)$ is shown in Eq. (1).

$\widetilde{v}=\widetilde{v}_{\text {dust }}+\left(\widetilde{v}_{\text {org }}-\widetilde{v}_{\text {dust }}\right) \times(1+\gamma) \times f_{\mathrm{ONO}_{2}}$,

where $\widetilde{v}_{\text {org }}$ and $\widetilde{v}_{\text {dust }}$ represent the specific volume of aerosol organic and inorganic components, respectively, while $\gamma$ is the mass ratio of the non-nitrate-containing organics to the organic nitrate group. Note here that the $p \Sigma \mathrm{AN}$ measurement is insensitive to inorganic nitrate ions and allowed us to use it as an unambiguous tracer for organic components in the aerosol phase. Equation (1) predicts a linear relationship between the aerosol specific volume and organic nitrate mass fraction given that organic nitrates represent a constant fraction in the organic mass, a condition satisfied as demonstrated in Fig. 4.

The $y$ intercept of a plot of aerosol specific volume versus organic nitrate mass fraction gives the specific volume of the inorganic component directly. We obtained a value of $0.168 \mathrm{~cm}^{3} \mathrm{~g}^{-1}$, corresponding to a nominal density of the inorganic component of $5.95 \mathrm{~g} \mathrm{~cm}^{-3}$, a value similar to iron(III) oxide $\left(d=5.24 \mathrm{~g} \mathrm{~cm}^{-3}\right)$. Organic molecules with moderate oxygenation have a density $\left(\widetilde{v}_{\text {org }}^{-1}\right)$ of approximately $0.85 \mathrm{~g} \mathrm{~cm}^{-3}$ (for example, 1-butyl nitrate $(d=0.882)$, tertbutyl nitrate $(d=0.867)$, nonanol $(d=0.827)$ and butanol $(d=0.81))$. Using this estimate, we obtain a $\gamma$ value of 11 . This constrains the organic mass associated with organic nitrate group in aerosol to approximately $680 \mathrm{amu}$. This associated mass estimated from the light component of the ambient aerosol typically accounts for $53 \%$ of the observed aerosol volume and $14 \%$ of the aerosol mass.

It is possible to account for the contribution of soluble inorganic salts that are measured by PILS by subtracting out an inorganic salt component defined by the sum of $\mathrm{NH}_{4}^{+}, \mathrm{NO}_{3}^{-}$ and $\mathrm{SO}_{4}^{2-}$ groups and their average density of $1.76 \mathrm{~g} \mathrm{~cm}^{-3}$. The sum of PILS ions can at times account for up to $50 \%$ of $\mathrm{PM}_{2.5}$ mass. The adjusted aerosol volume and mass after the subtraction of salt component is then analyzed using the same technique as above to extract a heavy and a light component. The $R^{2}$ value of 0.6 for the correlation of spe- 


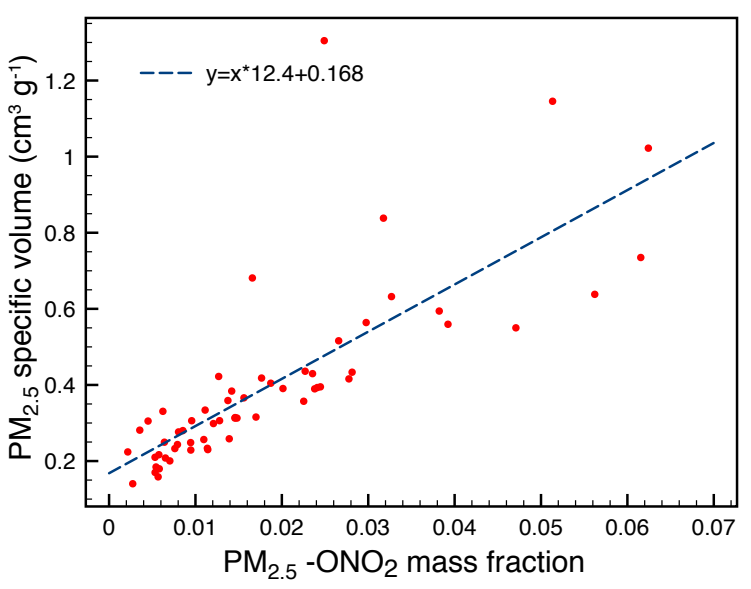

Figure 4. Correlation of specific volume (inverse density) to the mass fraction of the aerosol organic nitrate for $\mathrm{PM}_{2.5}$ size range $\left(R^{2}=0.6\right)$.

cific volume to organic nitrate mass fraction is identical to the correlation presented above. A $\gamma$ value of 9.6 is derived from this analysis

We can now constrain the molecular formula of particulate organic components using this corrected $\gamma$ value derived above. Together with aerosol mass spectrometer observations during high aerosol loading periods of an $\mathrm{O}: \mathrm{C}$ value of 0.2 (S. Murphy, personal communication, 2013) and a generic chemical formula containing carbon, oxygen, hydrogen and organic nitrate $\left(-\mathrm{ONO}_{2}\right)$ of the form $\left(\mathrm{CH}_{2}\right)_{n} \mathrm{O}_{m}\left(\mathrm{HONO}_{2}\right)$ for a fully saturated molecule, we derive an elemental ratio of $\mathrm{C}: \mathrm{H}: \mathrm{O}: \mathrm{N}=34: 69: 10: 1$. Note that any linear combination of organic molecule mixtures giving the same average $\mathrm{C}: \mathrm{H}: \mathrm{O}: \mathrm{N}$ ratio can satisfy this constraint, and may consist of both nitrates and non-nitrates.

The range of $\mathrm{C}: \mathrm{H}: \mathrm{O}: \mathrm{N}$ ratios consistent with the observations can be estimated from the confidence interval associated with the slope and intercept of the linear regression in Fig. 4. At $95 \%$ confidence interval, we estimate the uncertainty of the $\gamma$ value to be $\pm 17 \%$, given an organic matter density of $0.85 \mathrm{~g} \mathrm{~cm}^{-3}$. We point out that the large uncertainty in the $y$ intercept does not contribute significantly to the uncertainty of the result because the difference in specific volume is dominated by the organic component. Propagating this range gives $\mathrm{C}: \mathrm{H}: \mathrm{O}: \mathrm{N}$ ratio between $28: 57: 9: 1$ and $40: 81: 11: 1$. Note that, although the estimated carbon number appears to be high relative to the implied carbon number for organic aerosol generated from the Deepwater Horizon plume (de Gouw et al., 2011), our estimate is relative to the organic nitrate functional group in the aerosol phase. The implication is that not all organics responsible for organic aerosol formation during UBWOS contained organic nitrate groups.

\subsection{Daytime production}

In the following section we attempt to close the daytime $p \Sigma A N$ budget using gas-phase oxidation of aliphatic molecules followed by partitioning of oxidation products into the aerosol phase.

$\mathrm{p} \Sigma \mathrm{AN}$ is thought to be exclusively secondary. Consider daytime processes in the alkane-rich environment observed during UBWOS: the oxidation of an organic molecule $\mathrm{R}$ starts with a reaction with $\mathrm{OH}$ radical. For a simplified schematic (Reactions R1 and R2) of a single oxidation step in the presence of $\mathrm{NO}$, two generic products are formed with relative yields governed by the organic nitrate yield $\alpha$.

$$
\begin{aligned}
& \alpha \mathrm{R}+\mathrm{OH} \rightarrow \mathrm{R}\left(\mathrm{ONO}_{2}\right) \\
& (1-\alpha) \quad \mathrm{R}+\mathrm{OH} \rightarrow \mathrm{RO}
\end{aligned}
$$

The simple alkyl nitrate $\mathrm{R}\left(\mathrm{ONO}_{2}\right)$ and products formed from the subsequent reactions of alkoxy radical RO are assumed to partition into the aerosol phase as a function of their respective vapor pressure. If the partitioning follows ideal solution behavior within the existing aerosol organics, the fraction of the organic products expected to end up in the condensed phase is represented as $K_{\mathrm{p}}$ in Eq. (2), where $P^{*}$ represents the saturation vapor pressure of the organic molecule, $N_{\text {org }}$ the amount of organic molecules in the condensed phase in mol m $\mathrm{m}^{-3}$ and $k_{B}$ as Boltzmann's constant.

$K_{\mathrm{p}}=\frac{1}{1+\frac{P^{*}}{N_{\mathrm{org}} k_{B} T}}$

The largest alkane reported during UBWOS 2012 was undecane $\left(\mathrm{C}_{11} \mathrm{H}_{24}\right)$. Using a power law we extrapolate the $\mathrm{OH}$ reactivity of larger alkanes by fitting a linear relationship $\left(R^{2}=0.99\right)$ to the observed $\mathrm{C}_{9} \sim \mathrm{C}_{11}$ alkane reactivity in the $\log$ space. This approximation combines the decay in gasphase concentration due to reduction in vapor pressure and the increase in alkane $\mathrm{OH}$ reactivity with alkane size to generate a complete set of alkane consumption rates due to $\mathrm{OH}$ reactions. We then estimate the properties of the $\mathrm{OH}$ oxidation products from alkanes using a simplified scheme of three species for each carbon number group: an alkyl nitrate, a hydroxy nitrate and a hydroxy carbonyl, with branching ratios of $\alpha,(1-\alpha) \alpha$ and $(1-\alpha)^{2}$, respectively, as detailed in Appendix B. The absolute contribution of each type of oxidation product to aerosol formation is therefore the individual formation rate weighted by $K_{\mathrm{p}}$. The total aerosol yield attributable to this mechanism is obtained by summing the yield over all carbon number groups above $\mathrm{C}_{6}$. We used $\alpha$ values estimated with the method by Carter and Atkinson (1989) updated by Arey et al. (2001) at the appropriate temperature and pressure. The saturation vapor pressure $P^{*}$ of the reaction products follows the parameterization of SIMPOL.1 (Pankow and Asher, 2008).

Using this procedure, we calculate the particulate nitrate formation rate for the daytime period of 30 January, dur- 


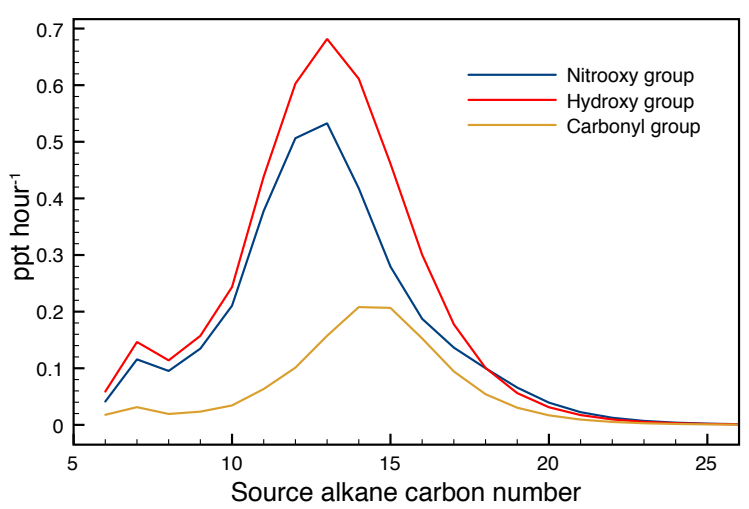

Figure 5. Source strength of functional groups for molecules contributing to aerosol formation on 30 January categorized by carbon number.

ing which time the aerosol loading peaked at $2 \mu \mathrm{g} \mathrm{m}^{-3}$. Using an approximate daytime $\mathrm{OH}$ concentration of $10^{6} \mathrm{~cm}^{-3}$ (Edwards et al., 2013), the total production rate of aerosolphase organic nitrate groups is $3.4 \mathrm{ppth}^{-1}$. The condensable molecules responsible for carrying the nitrooxy groups into the aerosol phase have carbon chain lengths in the range of $\mathrm{C}_{10}$ to $\mathrm{C}_{17}$, as shown in Fig. 5. The representative $\mathrm{C}: \mathrm{H}: \mathrm{O}: \mathrm{N}$ ratio of aerosol organics predicted by this alkane-only estimation is $18: 37: 5: 1$, or a non-nitrate to nitrate mass ratio of $4.5: 1$. This is about half of the value inferred directly from observations $(\gamma=9.6)$. One possible explanation for the difference is that approximately half of the non-nitrate carbonaceous component originates from oxidation of aromatic compounds ( $\sim 10 \%$ of alkanes $\mathrm{OH}$ reactivity) or primary sources. Uncertainties in the saturation vapor pressure and deviation from ideal solution behavior may also contribute.

The result obtained above only utilizes the alkane composition data. Independently, the total production rate of $p \Sigma A N$ can be calculated using time series of the measured $p \Sigma \mathrm{AN}$ concentration by solving the following mass balance equation (Eq. 3):

$p(p \Sigma \mathrm{AN})=\frac{d(p \Sigma \mathrm{AN})}{\mathrm{d} t}+k_{\text {mix }} \times p \Sigma \mathrm{AN}$.

Briefly, the total production rate of $p \Sigma \mathrm{AN}(p(p \Sigma \mathrm{AN}))$ is the rate of change of $p \Sigma \mathrm{AN}$ concentration plus the loss rate. The loss is represented as a first-order process with a loss rate constant $k_{\text {mix }}\left(\mathrm{s}^{-1}\right)$ which can be estimated using the known production rate and concentration of $n$-propyl nitrate as a tracer (Lee et al., 2014). Turbulent mixing-out of the basin was the dominant driver of $k_{\text {mix }}$. The inferred production rate during the same daytime period as the above analysis is $3.6 \mathrm{ppth}^{-1}$, nearly identical to the estimate using alkane composition. It is noted that, by assuming the same loss characteristics as $n$-propyl nitrate, the effect of dry deposition is likely underestimated. Alternatively, the $p \Sigma \mathrm{AN}$ formation rate calculated using loss characteristics of $\mathrm{HNO}_{3}$ yields a daytime production rate that is $21 \%$ higher $\left(4.4 \mathrm{ppth}^{-1}\right)$. This is likely an upper limit.

\section{$4.3 \mathrm{NO}_{3} / \mathrm{N}_{2} \mathrm{O}_{5}$ chemistry}

In addition to daytime source of $p \Sigma$ ANs, nighttime chemical production may also be important. The dominant reactions are typically those initiated by $\mathrm{NO}_{3}$ and $\mathrm{N}_{2} \mathrm{O}_{5}$ radicals, either through gas-phase oxidation followed by condensation or through heterogeneous reactions on the surface of existing organic aerosol. Due to cold temperatures that make gasphase reactions of $\mathrm{NO}_{3}$ less important by shifting the equilibrium towards $\mathrm{N}_{2} \mathrm{O}_{5}$, as well as the scarcity of unsaturated hydrocarbons observed, the condensation pathway is likely unimportant. Multiple lab studies on both environmental and synthesized aerosol particles (Gross et al., 2009; Zhao et al., 2011a, b; Xiao and Bertram, 2011; Bertram et al., 2009) have demonstrated that the reactive uptake of $\mathrm{NO}_{3}$ or $\mathrm{N}_{2} \mathrm{O}_{5}$ can be significant, and for certain class of organics molecules (e.g., alkenes and alcohols) can give high yield of organic nitrates as condensed-phase products. As opposed to daytime analysis, it is difficult to directly estimate the net nocturnal $p \Sigma \mathrm{AN}$ production with Eq. (3) due to the lack of concentration variation and difficulty in estimating the loss term. However, we found that inclusion of heterogeneous production is necessary to explain the nighttime concentration of $p \Sigma \mathrm{AN}$ and we characterize the heterogeneous reactions in the following modeling section.

\subsection{Modeling the aerosol time series}

A box model incorporating the above daytime and nighttime mechanisms was used to simulate the organic nitrate content of the aerosol.

The observed $\Sigma \mathrm{AN}$ is assumed to represent the total concentration of organic nitrates produced due to photochemistry as described in Lee et al. (2014), with an effective saturation vapor pressure as a tuning parameter to determine the effective partitioning based on Eq. (2). The bidirectional exchange is calculated according to gas kinetic theory and detailed balance derived from the saturation vapor pressure accounting for the Kelvin effect.

For the nighttime chemistry, we introduce a new parameter, the retaining coefficient $(\zeta)$, defined as the probability of reactive uptake yielding condensed-phase organic nitrates given a gas molecule-surface collision. This differs from the reactive uptake coefficient by excluding non-nitrate forming channels. The $p \Sigma \mathrm{AN}$ production is calculated from gas molecule-surface collision rate corrected for diffusion transport and then multiplied by $\zeta$. The organic nitrates formed through this pathway are assumed to remain in the condensed phase.

Loss of $\mathrm{p} \Sigma$ ANs is assumed to follow the loss of aerosols. The most important process is turbulent mixing, with a lifetime of $\sim 8 \mathrm{~h}$ during daytime periods. The full time series of 

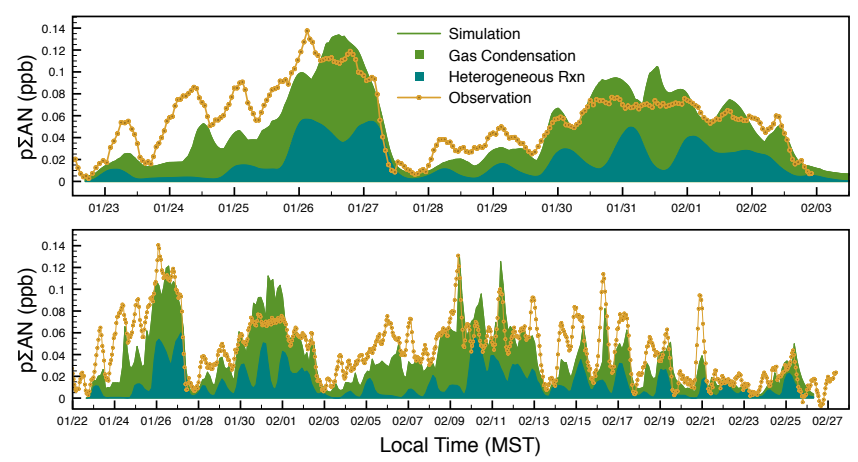

Figure 6. Time series of predicted particulate organic nitrate concentration from box model simulation for two accumulation events (top panel) and the campaign period (bottom panel) as stacked areas showing contribution from each of the two mechanisms responsible. The observations are plotted in yellow.

first-order loss rate is calculated using tracer methods (Lee et al., 2014) and applied to the simulation. We used $\mathrm{HNO}_{3}$ to estimate the loss rate which gives a more realistic loss profile during the evening, when the boundary layer is stable.

The resulting time series of predicted concentrations are shown in Fig. 6, where the top panel describes the two consecutive accumulation periods and the lower panel extends the simulation to all observations. We find an effective saturation vapor pressure of $26 \mathrm{ppb}$ for the ensemble of total organic nitrate species and $\mathrm{NO}_{3}$ reactive uptake coefficient $\zeta_{\mathrm{NO}_{3}}$ of 0.1 for the full length of simulation. The model is highly correlated with the observations (slope of 0.98 and $R^{2}$ value of 0.72 ) over the 2 -week period shown in the top panel of Fig. 6. A reduced correlation with a slope of 0.72 and an $R^{2}$ of 0.66 is observed for the full data (bottom panel of Fig. 6). This fitted effective saturation vapor pressure is consistent with one calculated from the VOC speciation $(28 \mathrm{ppb}$ $\Sigma$ ANs). The major discrepancies in the extended simulation arise when organic aerosol mass becomes more abundant in the super- $0.5 \mu \mathrm{m}$ size range (up to $36 \%$ of total $p \Sigma \mathrm{ANs}$ ), particularly during the period from 12 to 21 February. It is possible that organics were present as external coatings on the inorganic minerals of large size particles, leading to an enhanced surface to volume ratio relative to a pure particle of the same organic mass. The result is underestimation in predicted organic nitrate content due to discrepancies in the aerosol mixing state. Also, the possibilities of secondary chemistry in the presence of inorganic salts cannot be ruled out.

The $\zeta_{\mathrm{NO}_{3}}$ value of 0.1 should be interpreted as a projection of the overall reactivity onto $\mathrm{NO}_{3}$ reactions, since $\mathrm{NO}_{3}$ and $\mathrm{N}_{2} \mathrm{O}_{5}$ interconvert rapidly and both species may contribute to heterogeneous reactions. Given an observed median $\mathrm{NO}_{3} / \mathrm{N}_{2} \mathrm{O}_{5}$ ratio of 0.007 , the heterogeneous chemistry may be equally satisfied with an $\mathrm{N}_{2} \mathrm{O}_{5}$-based $\zeta_{\mathrm{N}_{2} \mathrm{O}_{5}}$ of $8 \times 10^{-4}$, or any linear combination of the two chan- nels. However, we point out that due to the enhancement of $\mathrm{N}_{2} \mathrm{O}_{5}$ lifetime as a result of the cold temperature and high $\mathrm{NO}_{x}$ concentrations encountered, the heterogeneous reaction cannot be dominated by $\mathrm{NO}_{3}$ as this requires a value of $\zeta_{\mathrm{NO}_{3}}$ larger than even aerosols made of pure unsaturated organic molecules such as solidified oleic acid $\left(\gamma \mathrm{NO}_{3}=0.076\right)$ and conjugated linoleic acid $\left(\gamma \mathrm{NO}_{3}=0.08\right)$ as observed in laboratory studies (Gross et al., 2009). Therefore, $\mathrm{N}_{2} \mathrm{O}_{5}-$ dominated heterogeneous reactions with hydroxy groups in the aerosol phase are a more likely source of nighttime $p \Sigma A N$ production, and are within range of reported reactive uptake coefficient measured on surface of glycerol particles $\left(\gamma_{\mathrm{N}_{2} \mathrm{O}_{5}}=8.14 \times 10^{-4}\right)$ and wintertime aerosol in Colorado $\left(\gamma_{\mathrm{N}_{2} \mathrm{O}_{5}} \sim 0.01\right)$ (Wagner et al., 2013). More laboratory experiments with emphasis on condensed-phase products under low-temperature conditions are necessary to verify the values obtained here for saturated organic aerosol systems. Finally, it is noted that the nocturnal production of $p \Sigma \mathrm{ANs}$ $\left(6 \mathrm{ppth}^{-1}\right)$ does not constitute a significant local sink of $\mathrm{NO}_{3}$ (production rate of $150 \mathrm{ppth}^{-1}$ ).

\section{Implications}

Our particulate organic nitrate measurements during wintertime in the Uintah Basin, Utah, represent a unique opportunity to characterize the chemistry of alkane-derived SOA under ambient (albeit cold) conditions. This is relevant to environments when anthropogenic activities heavily influence the VOC composition. According to the study of Gentner et al. (2012), both gasoline and diesel fuel sampled at various locations in California were primarily alkanes, with an overall longer chain length in the diesel fuel. Tailpipe emissions of unburnt diesel fuel as well as motor oil (Worton et al., 2014) may represent the predominant source for large alkanes observed in cities (Boynard et al., 2014). For example, VOC enhancement ratios observed in Los Angeles showed a non-decreasing trend from $n$-nonane to undecane, the largest alkane reported (Borbon et al., 2013). Similar mixing ratios have also been observed in Sacramento, California (Steiner et al., 2008). This is different from the decreasing trend observed in Utah, where the VOC sources are evaporative, but rather consistent with the composition from direct emissions of liquid diesel for which the distribution of $\mathrm{C}_{10}$ to $\mathrm{C}_{20}$ alkanes are relatively flat.

We calculated the potential organic nitrate aerosol formation from alkanes using the liquid fuel composition tabulated in the supporting information of Gentner et al. (2012) and the partitioning method detailed in Sect. 4.2 for $\mathrm{OH}$-initiated oxidation. $\mathrm{OH}$ reaction rates for alkanes larger than dodecane are parameterized (Kwok and Atkinson, 1995). For an organic aerosol loading of $2 \mu \mathrm{g} \mathrm{m}^{-3}$, the organic nitrate aerosol yield is $14 \mathrm{wt} \%$ for diesel fuel and $0.004 \mathrm{wt} \%$ for gasoline, both calculated at $298 \mathrm{~K}$. Since it was estimated by Gentner et al. (2012) that both gasoline and diesel vehicles emit a 
similar amount of VOC by weight in the Bakersfield region (Kern county), a ratio of $44 \%$ (gasoline) to $56 \%$ (diesel), the diesel emission dominates the source strength of particulate organic nitrates. We further estimate the potential $p \Sigma \mathrm{AN}$ concentrations according to the mass yield calculated above and tailpipe VOC emission of $7 \mu \mathrm{g} \mathrm{m}^{-3}$ from diesel vehicles, a number we derived based on the SOA production estimation in Gentner et al. (2012). The result is $46 \mathrm{ppt} p \Sigma \mathrm{AN}$ due to diesel traffic emissions in the Bakersfield region, a value accounting for $77 \%$ of the observed daytime ambient concentration by Rollins et al. (2013), who reported local $p \sum \mathrm{AN}$ concentration of $\sim 60 \mathrm{ppt}$ during daytime periods of the CalNex 2012 campaign. Contributions from local biogenic precursors as well as fugitive losses from oil and gas productions may account for the remaining particulate nitrates. However, we point out that photochemical aging is required to achieve the yield from our estimation and the above value should be interpreted as an upper limit.

The above example of particulate organic nitrate production around Bakersfield region illustrates the possibility of distinct pathways responsible between daytime and nighttime periods. The saturated but much heavier alkanes will contribute during the day from $\mathrm{OH}$ oxidation and partition more efficiently into the aerosol phase, while the more reactive but generally lighter biogenic emissions may dominate nighttime production due to $\mathrm{NO}_{3}$ and $\mathrm{N}_{2} \mathrm{O}_{5}$ chemistry. This is of particular interest in regions with representative VOCs consisting of a mixture of anthropogenic and biogenic contributions.

\section{Conclusions}

We present $\mathrm{PM}_{2.5}$ particulate organic nitrate concentration measurements obtained in wintertime Utah using the TDLIF technique. Of the median $1 \mu \mathrm{g} \mathrm{m}^{-3}$ organic aerosol estimated, we found organic nitrate to be a consistent portion of the organic mass within the sub- $0.5 \mu \mathrm{m}$ particle size ranges with an average $\mathrm{C}: \mathrm{H}: \mathrm{O}: \mathrm{N}$ elemental composition of $34,69: 10: 1$, likely as a mixture of $C_{10}$ to $C_{17}$ organic nitrates and oxygenates. With the help of a box model, we demonstrate that the particulate organic nitrate concentration observed can be reproduced by gas-phase condensation and heterogeneous chemistry of $\mathrm{N}_{2} \mathrm{O}_{5}$. Both channels contribute almost equally, consistent with the lack of day-night change observed in condensed-phase organic nitrate content. By applying our analysis to the California central valley region, we demonstrate that diesel tailpipe emissions can potentially contribute to a significant portion of ambient particulate organic nitrates observed. 


\section{Appendix A: Derivation for aerosol specific volume-nitrate concentration relationship}

The third panel in Fig. 1 shows the relative importance of total aerosol volume contributions from particles above or under $500 \mathrm{~nm}$ size. While we have demonstrated the relative domination of organic/inorganic component has a rough boundary at $500 \mathrm{~nm}$, simply treating this as a cut-off point will likely lead to non-negligible underestimation of organic component that exists in the over $500 \mathrm{~nm}$ size range which contained about half of total $\mathrm{PM}_{2.5}$ aerosol volume. We therefore propose a method that utilizes our $\mathrm{PM}_{2.5} p \Sigma \mathrm{AN}$ data as tracers and without assumptions made on the organic content of the various aerosol size ranges. This method is based on the observation that mineral dust or inorganic salts generally have higher density than organic molecules. Instead of focusing on the metric of density, which is not an additive parameter, specific volume (or inverse density in $\mathrm{cm}^{3} \mathrm{~g}^{-1}$ ) is used to factor out the inorganic component by linear combination. Within the particular environment of wintertime Uintah Basin, we assume no significant aqueousphase present. As mineral dust and salt are not typically soluble in organic phase, the total volume of the aerosol can be treated as a linear combination of volumes from individual immiscible components, such as the equations presented below:

$\widetilde{v}=\sum_{i} \widetilde{v}_{i} \times f_{i}$,

$\sum_{i} f_{i}=1$.

In Eq. (A1), $\widetilde{v}$ is the overall specific volume of the $\mathrm{PM}_{2.5}$ aerosol phase, while $\widetilde{v}_{i}$ and $f_{i}$ are specific volume and mass fraction of component $i$ in the aerosol phase, respectively. Mass fractions from all aerosol components should add up to 1 (Eq. A2). We now name three components in the aerosol phase to be considered explicitly. The first component, $f_{\text {dust }}$, collectively represents the inorganic components, including mineral dust and salt. The second and third components both represent the organic phase, but were broken down in terms of functionality. We represent the organic nitrate group functionality as $f_{\mathrm{ONO}_{2}+\mathrm{H}}$ and the rest of the organic group as $f_{\mathrm{CH}_{2}}$. The presence of oxygenated groups is treated by further breaking down the $f_{\mathrm{CH}_{2}}$ component. For the time being, this effectively represents the organic molecules as a nominal formula of $\mathrm{H}\left(\mathrm{CH}_{2}\right)_{n}\left(\mathrm{ONO}_{2}\right)_{m}$. The explicit inclusion of one extra hydrogen to the $-\mathrm{ONO}_{2}$ group is for valence balance of a fully saturated molecule. The resulting representation for $\widetilde{v}$ is therefore

$\widetilde{v}=\widetilde{v}_{\text {dust }} \times f_{\text {dust }}+\widetilde{v}_{\mathrm{ONO}_{2}} \times f_{\mathrm{ONO}_{2}+\mathrm{H}}+\widetilde{v}_{\mathrm{CH}_{2}} \times f_{\mathrm{CH}_{2}}$.

Since it was observed that the nitrate group is a rather consistent component of the organic aerosols (Fig. 3), we expect $f_{\mathrm{CH}_{2}}$ to vary with $f_{\mathrm{ONO}_{2}+\mathrm{H}}$ by a constant coefficient $\gamma$, so that $f_{\mathrm{CH}_{2}}=\gamma \times f_{\mathrm{ONO}_{2}+\mathrm{H}}$. This gives us Eq. (A4):

$\widetilde{v}=\widetilde{v}_{\text {dust }} \times f_{\text {dust }}+\left(\widetilde{v}_{\mathrm{ONO}_{2}}+\gamma \times \widetilde{v}_{\mathrm{CH}_{2}}\right) \times f_{\mathrm{ONO}_{2}+\mathrm{H}}$.

By further assuming that the specific volume of the nitrate group is the same as the $\mathrm{CH}_{2}$ fragment in a large organic molecule (subsequently called $\widetilde{v}_{\text {org }}$ ) and using the constraint from Eq. (A2) to substitute for $f_{\text {dust }}$, we arrive at Eq. (A5), which we may simplify into Eq. (A6) (or Eq. 1 in the main text) by rearrangement of terms and replacing $f_{\mathrm{ONO}_{2}+\mathrm{H}}$ with $f_{\mathrm{ONO}_{2}}$, since the mass of a hydrogen is small compared to the mass of a nitrooxy group.

$$
\begin{aligned}
\widetilde{v}= & \widetilde{v}_{\text {dust }} \times\left[1-(1+\gamma) \times f_{\mathrm{ONO}_{2}+\mathrm{H}}\right]+(1+\gamma) \\
& \times \widetilde{v}_{\text {org }} \times f_{\mathrm{ONO}_{2}+\mathrm{H}} \\
\widetilde{v}= & \widetilde{v}_{\text {dust }}+\left(\widetilde{v}_{\text {org }}-\widetilde{v}_{\text {dust }}\right) \times(1+\gamma) \times f_{\mathrm{ONO}_{2}}
\end{aligned}
$$

We see that Eq. (A6) predicts a linear relationship between $\mathrm{PM}_{2.5}$ specific volume and mass fraction of the nitrooxy group in the aerosol phase, under conditions where the inorganic and organic components have relatively constant specific mass. We demonstrate that this relation is indeed observed during UBWOS 2012 in Fig. 4.

\section{Appendix B: Estimation of $\Sigma \mathrm{AN}$ contribution using extrapolated VOC reactivity}

To estimate specific contributions of organic nitrates to the aerosol formation, we traced oxidation of long-chain alkanes up to the second-generation $\mathrm{RO}_{2}$ products. Considering a simple alkane $\mathrm{R}$, the dominant $\mathrm{OH}$ reaction is an abstraction of hydrogen to give the first-generation $\mathrm{RO}_{2}$ radical, which upon reaction with abundant NO during UBWOS condition leads to alkyl nitrate compound $\mathrm{R}\left(\mathrm{ONO}_{2}\right)$ and alkoxy radical $\mathrm{RO}$ of relative yield $\alpha$ and $(1 \alpha)$. For $\mathrm{R}$ with carbon chain length over six, the isomerization dominates the fate of RO by hydrogen abstraction within the same molecule through a six-membered ring transition state (rate constant typically $>10^{4} \mathrm{~s}^{-1}$ ). The result is a hydroxy peroxy radical upon reaction with $\mathrm{O}_{2}$ (second-generation $\mathrm{RO}_{2}$ ). The same NO reaction proceeds to give a second-generation hydroxy nitrate $\mathrm{R}(\mathrm{OH})\left(\mathrm{ONO}_{2}\right)$ and a hydroxy alkoxy radical, which may promptly react $\left(>10^{5} \mathrm{~s}^{-1}\right)$ with the hydrogen on the hydroxy group carbon to give a hydroxy carbonyl $\mathrm{R}(=\mathrm{O})(\mathrm{OH})$, which is assumed to represent the rest of the non-nitrate functionality under our simplification. It is also assumed that the organic nitrate yield is not affected by the presence of non-neighboring $\mathrm{OH}$ groups, giving the simplified branching ratios shown in Reactions (BR1) to (BR3). We then calculate the vapor pressure of each molecule surrogate using group contribution method SIMPOL.1, of a given car- 
bon chain length in the R group at $273 \mathrm{~K}$.

$$
\begin{array}{rlll}
\alpha & \mathrm{R}+\mathrm{OH} & \rightarrow \mathrm{R}\left(\mathrm{ONO}_{2}\right) & (\mathrm{BR} 1) \\
(1-\alpha) \times \alpha & \mathrm{R}+\mathrm{OH} & \rightarrow \mathrm{R}(\mathrm{OH})\left(\mathrm{ONO}_{2}\right) & (\mathrm{BR} 2) \\
(1-\alpha)^{2} & \mathrm{R}+\mathrm{OH} & \rightarrow \mathrm{R}(=\mathrm{O})(\mathrm{OH})
\end{array}
$$

In order to obtain a converging estimation with respect to the long-carbon chain end of the VOC spectrum, it is necessary to extrapolate the contribution of heavy VOCs beyond the measurement which terminates at undecane. Using a linear fit in the log space of the grouped VOC reactivity with specific carbon number, we obtained an estimation, shown in Eq. (B1), for the 30 January accumulation period:

$\ln (k x)=-0.5893 \times n+3.9223$,

$S_{n}\left\{\mathrm{R}(\mathrm{OH})\left(\mathrm{ONO}_{2}\right)\right\}=k x \times[\mathrm{OH}] \times(1-\alpha)$

$\times \alpha \times K_{\mathrm{p}}$,

where $k x$ is the total reactivity in units of $\mathrm{s}^{-1}$ of alkanes with carbon number $n$. The total aerosol source of each molecule type within each carbon number class is then calculated in the same way shown for the hydroxy nitrates of size $n$ (Eq. B2). Note that $K_{\mathrm{p}}$ is the fraction of the species in the aerosol phase, calculated using Eq. (2) in the main text. The total nitrate groups incorporated into the aerosol phase are then calculated by summing over all carbon groups of alkyl nitrates and hydroxy nitrates. Other functional groups are calculated similarity with application of appropriate weightings. For example, the total $\mathrm{CH}_{2}$ group contribution is calculated according to Eq. (B3).

$$
\begin{aligned}
& \sum_{n} n \times\left(S_{n}\left\{\mathrm{R}\left(\mathrm{ONO}_{2}\right)\right\}+S_{n}\left\{\mathrm{R}(\mathrm{OH})\left(\mathrm{ONO}_{2}\right)\right\}\right. \\
& \left.+S_{n}\{\mathrm{R}(=\mathrm{O})(\mathrm{OH})\}\right)
\end{aligned}
$$


Acknowledgements. The Berkeley authors acknowledge the support of the NOAA Office of Global Programs (NA13OAR4310067) and the NSF (grant AGS-1120076). This is PMEL contribution number 4293. The authors also acknowledge the help of Carsten Warneke for preparation of the manuscript.

Edited by: J. Collett

\section{References}

Arey, J., Aschmann, S. M., Kwok, E. S. C., and Atkinson, R.: Alkyl nitrate, hydroxyalkyl nitrate, and hydroxycarbonyl formation from the NOx-air photooxidations of C-5-C-8 n-alkanes, J. Phys. Chem. A, 105, 1020-1027, doi:10.1021/jp003292z, 2001.

Bahreini, R., Middlebrook, A. M., de Gouw, J. A., Warneke, C., Trainer, M., Brock, C. A., Stark, H., Brown, S. S., Dube, W. P., Gilman, J. B., Hall, K., Holloway, J. S., Kuster, W. C., Perring, A. E., Prevot, A. S. H., Schwarz, J. P., Spackman, J. R., Szidat, S., Wagner, N. L., Weber, R. J., Zotter, P., and Parrish, D. D.: Gasoline emissions dominate over diesel in formation of secondary organic aerosol mass, Geophys. Res. Lett., 39, L06805, doi:10.1029/2011g1050718, 2012.

Bertram, T. H., Thornton, J. A., Riedel, T. P., Middlebrook, A. M., Bahreini, R., Bates, T. S., Quinn, P. K., and Coffman, D. J.: Direct observations of $\mathrm{N}_{2} \mathrm{O}_{5}$ reactivity on ambient aerosol particles, Geophys. Res. Lett., 36, L19803, doi:10.1029/2009g1040248, 2009.

Borbon, A., Gilman, J. B., Kuster, W. C., Grand, N., Chevaillier, S., Colomb, A., Dolgorouky, C., Gros, V., Lopez, M., Sarda-Esteve, R., Holloway, J., Stutz, J., Petetin, H., McKeen, S., Beekmann, M., Warneke, C., Parrish, D. D., and de Gouw, J. A.: Emission ratios of anthropogenic volatile organic compounds in northern mid-latitude megacities: Observations versus emission inventories in Los Angeles and Paris, J. Geophys. Res.-Atmos., 118, 2041-2057, doi:10.1002/jgrd.50059, 2013.

Boynard, A., Borbon, A., Leonardis, T., Barletta, B., Meinardi, S., Blake, D. R., and Locoge, N.: Spatial and seasonal variability of measured anthropogenic non-methane hydrocarbons in urban atmospheres: Implication on emission ratios, Atmos. Environ., 82, 258-267, doi:10.1016/j.atmosenv.2013.09.039, 2014.

Brown, S. S., deGouw, J. A., Warneke, C., Ryerson, T. B., Dubé, W. P., Atlas, E., Weber, R. J., Peltier, R. E., Neuman, J. A., Roberts, J. M., Swanson, A., Flocke, F., McKeen, S. A., Brioude, J., Sommariva, R., Trainer, M., Fehsenfeld, F. C., and Ravishankara, A. R.: Nocturnal isoprene oxidation over the Northeast United States in summer and its impact on reactive nitrogen partitioning and secondary organic aerosol, Atmos. Chem. Phys., 9, 30273042, doi:10.5194/acp-9-3027-2009, 2009.

Carter, W. P. L. and Atkinson, R.: Alkyl Nitrate Formation From the Atmospheric Photooxidation of Alkanes - a Revised Estimation Method, J. Atmos. Chem., 8, 165-173, doi:10.1007/bf00053721, 1989.

Day, D. A., Wooldridge, P. J., Dillon, M. B., Thornton, J. A., and Cohen, R. C.: A thermal dissociation laser-induced fluorescence instrument for in situ detection of $\mathrm{NO}(2)$, peroxy nitrates, alkyl nitrates, and $\mathrm{HNO}(3)$, J. Geophys. Res.-Atmos., 107, ACH 4-1ACH 4-14, doi:10.1029/2001jd000779, 2002.
Day, D. A., Liu, S., Russell, L. M., and Ziemann, P. J.: Organonitrate group concentrations in submicron particles with high nitrate and organic fractions in coastal southern California, Atmos. Environ., 44, 1970-1979, doi:10.1016/j.atmosenv.2010.02.045, 2010.

de Gouw, J. A., Middlebrook, A. M., Warneke, C., Ahmadov, R., Atlas, E. L., Bahreini, R., Blake, D. R., Brock, C. A., Brioude, J., Fahey, D. W., Fehsenfeld, F. C., Holloway, J. S., Le Henaff, M., Lueb, R. A., McKeen, S. A., Meagher, J. F., Murphy, D. M., Paris, C., Parrish, D. D., Perring, A. E., Pollack, I. B., Ravishankara, A. R., Robinson, A. L., Ryerson, T. B., Schwarz, J. P., Spackman, J. R., Srinivasan, A., and Watts, L. A.: Organic Aerosol Formation Downwind from the Deepwater Horizon Oil Spill, Science, 331, 1295-1299, doi:10.1126/science.1200320, 2011.

Edwards, P. M., Young, C. J., Aikin, K., deGouw, J., Dubé, W. P., Geiger, F., Gilman, J., Helmig, D., Holloway, J. S., Kercher, J., Lerner, B., Martin, R., McLaren, R., Parrish, D. D., Peischl, J., Roberts, J. M., Ryerson, T. B., Thornton, J., Warneke, C., Williams, E. J., and Brown, S. S.: Ozone photochemistry in an oil and natural gas extraction region during winter: simulations of a snow-free season in the Uintah Basin, Utah, Atmos. Chem. Phys., 13, 8955-8971, doi:10.5194/acp-13-8955-2013, 2013.

Farmer, D. K., Matsunaga, A., Docherty, K. S., Surratt, J. D., Seinfeld, J. H., Ziemann, P. J., and Jimenez, J. L.: Response of an aerosol mass spectrometer to organonitrates and organosulfates and implications for atmospheric chemistry, P. Natl. Acad. Sci. USA, 107, 6670-6675, doi:10.1073/pnas.0912340107, 2010.

Froyd, K. D., Murphy, S. M., Murphy, D. M., de Gouw, J. A., Eddingsaas, N. C., and Wennberg, P. O.: Contribution of isoprene-derived organosulfates to free tropospheric aerosol mass, P. Natl. Acad. Sci. USA, 107, 21360-21365, doi:10.1073/pnas.1012561107, 2010.

Garnes, L. A. and Allen, D. T.: Size distributions of organonitrates in ambient aerosol collected in Houston, Texas, Aerosol Sci. Technol., 36, 983-992, doi:10.1080/02786820290092186, 2002.

Gentner, D. R., Isaacman, G., Worton, D. R., Chan, A. W. H., Dallmann, T. R., Davis, L., Liu, S., Day, D. A., Russell, L. M., Wilson, K. R., Weber, R., Guha, A., Harley, R. A., and Goldstein, A. H.: Elucidating secondary organic aerosol from diesel and gasoline vehicles through detailed characterization of organic carbon emissions, P. Natl. Acad. Sci. USA, 109, 18318-18323, doi:10.1073/pnas.1212272109, 2012.

Goldstein, A. H. and Galbally, I. E.: Known and unexplored organic constituents in the earth's atmosphere, Environ. Sci. Technol., 41, 1514-1521, doi:10.1021/es072476p, 2007.

Gordon, T. D., Tkacik, D. S., Presto, A. A., Zhang, M., Jathar, S. H., Nguyen, N. T., Massetti, J., Tin, T., Cicero-Fernandez, P., Maddox, C., Rieger, P., Chattopadhyay, S., Maldonado, H., Maricq, M. M., and Robinson, A. L.: Primary Gas- and ParticlePhase Emissions and Secondary Organic Aerosol Production from Gasoline and Diesel Off-Road Engines, Environ. Sci. Technol., 47, 14137-14146, doi:10.1021/es403556e, 2013.

Gross, S., Iannone, R., Xiao, S., and Bertram, A. K.: Reactive uptake studies of $\mathrm{NO}(3)$ and $\mathrm{N}(2) \mathrm{O}(5)$ on alkenoic acid, alkanoate, and polyalcohol substrates to probe nighttime aerosol chemistry, Phys. Chem. Chem. Phys., 11, 7792-7803, doi:10.1039/b904741g, 2009.

Hallquist, M., Wenger, J. C., Baltensperger, U., Rudich, Y., Simpson, D., Claeys, M., Dommen, J., Donahue, N. M., George, 
C., Goldstein, A. H., Hamilton, J. F., Herrmann, H., Hoffmann, T., Iinuma, Y., Jang, M., Jenkin, M. E., Jimenez, J. L., Kiendler-Scharr, A., Maenhaut, W., McFiggans, G., Mentel, Th. F., Monod, A., Prévôt, A. S. H., Seinfeld, J. H., Surratt, J. D., Szmigielski, R., and Wildt, J.: The formation, properties and impact of secondary organic aerosol: current and emerging issues, Atmos. Chem. Phys., 9, 5155-5236, doi:10.5194/acp-9-51552009, 2009.

Jathar, S. H., Miracolo, M. A., Tkacik, D. S., Donahue, N. M., Adams, P. J., and Robinson, A. L.: Secondary Organic Aerosol Formation from Photo-Oxidation of Unburned Fuel: Experimental Results and Implications for Aerosol Formation from Combustion Emissions, Environ. Sci. Technol., 47, 12886-12893, doi:10.1021/es403445q, 2013.

Jordan, C. E., Ziemann, P. J., Griffin, R. J., Lim, Y. B., Atkinson, R., and Arey, J.: Modeling SOA formation from $\mathrm{OH}$ reactions with C-8-C-17 n-alkanes, Atmos. Environ., 42, 8015-8026, doi:10.1016/j.atmosenv.2008.06.017, 2008.

Kleinman, M. T., Bhalla, D. K., Mautz, W. J., and Phalen, R. F.: Cellular and immunological injury with $\mathrm{PM}_{10}$ inhalation, Inhalation Toxicology, 7, 589-602, doi:10.3109/08958379509014467, 1995.

Kwok, E. S. C. and Atkinson, R.: Estimation of Hydroxyl Radical Reaction-Rate Constants for Gas-Phase Organic-Compounds Using a Structure-Reactivity Relationship - An Update, Atmos. Environ., 29, 1685-1695, doi:10.1016/1352-2310(95)00069-b, 1995.

Lee, L., Wooldridge, P. J., Gilman, J. B., Warneke, C., de Gouw, J., and Cohen, R. C.: Low temperatures enhance organic nitrate formation: evidence from observations in the 2012 Uintah Basin Winter Ozone Study, Atmos. Chem. Phys., 14, 12441-12454, doi:10.5194/acp-14-12441-2014, 2014.

Lewis, C. W., Klouda, G. A., and Ellenson, W. D.: Radiocarbon measurement of the biogenic contribution to summertime PM-2.5 ambient aerosol in Nashville, TN, Atmos. Environ., 38, 6053-6061, doi:10.1016/j.atmosenv.2004.06.011, 2004.

Lim, Y. B. and Ziemann, P. J.: Chemistry of Secondary Organic Aerosol Formation from $\mathrm{OH}$ Radical-Initiated Reactions of Linear, Branched, and Cyclic Alkanes in the Presence of NOx, Aerosol Sci. Technol., 43, 604-619, doi:10.1080/02786820902802567, 2009.

Matsunaga, A. and Ziemann, P. J.: Yields of BetaHydroxynitrates, Dihydroxynitrates, and Trihydroxynitrates Formed from $\mathrm{OH}$ Radical-Initiated Reactions of 2-Methyl1-Alkenes, P. Natl. Acad. Sci. USA, 107, 6664-6669, doi:10.1073/pnas.0910585107, 2010.

Mylonas, D. T., Allen, D. T., Ehrman, S. H., and Pratsinis, S. E.: The sources and size distributions of organonitrates in Los-Angeles aerosol, Atmos. Environ. A, 25, 2855-2861, doi:10.1016/09601686(91)90211-o, 1991.

Pankow, J. F. and Asher, W. E.: SIMPOL.1: a simple group contribution method for predicting vapor pressures and enthalpies of vaporization of multifunctional organic compounds, Atmos. Chem. Phys., 8, 2773-2796, doi:10.5194/acp-8-27732008, 2008.

Paulot, F., Crounse, J. D., Kjaergaard, H. G., Kuerten, A., St Clair, J. M., Seinfeld, J. H., and Wennberg, P. O.: Unexpected Epoxide Formation in the Gas-Phase Photooxidation of Isoprene, Science, 325, 730-733, doi:10.1126/science.1172910, 2009.
Roberts, J. M., Osthoff, H. D., Brown, S. S., Ravishankara, A. R., Coffman, D., Quinn, P., and Bates, T.: Laboratory studies of products of N2O5 uptake on Cl- containing substrates, Geophys. Res. Lett., 36, L20808, doi:10.1029/2009g1040448, 2009.

Rollins, A. W., Kiendler-Scharr, A., Fry, J. L., Brauers, T., Brown, S. S., Dorn, H.-P., Dubé, W. P., Fuchs, H., Mensah, A., Mentel, T. F., Rohrer, F., Tillmann, R., Wegener, R., Wooldridge, P. J., and Cohen, R. C.: Isoprene oxidation by nitrate radical: alkyl nitrate and secondary organic aerosol yields, Atmos. Chem. Phys., 9, 6685-6703, doi:10.5194/acp-9-6685-2009, 2009.

Rollins, A. W., Fry, J. L., Hunter, J. F., Kroll, J. H., Worsnop, D. R., Singaram, S. W., and Cohen, R. C.: Elemental analysis of aerosol organic nitrates with electron ionization high-resolution mass spectrometry, Atmos. Meas. Tech., 3, 301-310, doi:10.5194/amt3-301-2010, 2010a.

Rollins, A. W., Smith, J. D., Wilson, K. R., and Cohen, R. C.: Real Time In Situ Detection of Organic Nitrates in Atmospheric Aerosols, Environ. Sci. Technol., 44, 5540-5545, doi:10.1021/es100926x, 2010b.

Rollins, A. W., Browne, E. C., Min, K. E., Pusede, S. E., Wooldridge, P. J., Gentner, D. R., Goldstein, A. H., Liu, S., Day, D. A., Russell, L. M., and Cohen, R. C.: Evidence for NOx Control Over Nighttime SOA Formation, Science, 337, 1210-1212, doi:10.1126/science.1221520, 2012.

Rollins, A. W., Pusede, S., Wooldridge, P., Min, K. E., Gentner, D. R., Goldstein, A. H., Liu, S., Day, D. A., Russell, L. M., Rubitschun, C. L., Surratt, J. D., and Cohen, R. C.: Gas/particle partitioning of total alkyl nitrates observed with TDLIF in Bakersfield, J. Geophys. Res.-Atmos., 118, 6651-6662, doi:10.1002/jgrd.50522, 2013.

Shilling, J. E., Zaveri, R. A., Fast, J. D., Kleinman, L., Alexander, M. L., Canagaratna, M. R., Fortner, E., Hubbe, J. M., Jayne, J. T., Sedlacek, A., Setyan, A., Springston, S., Worsnop, D. R., and Zhang, Q.: Enhanced SOA formation from mixed anthropogenic and biogenic emissions during the CARES campaign, Atmos. Chem. Phys., 13, 2091-2113, doi:10.5194/acp-13-20912013, 2013.

Steiner, A. L., Cohen, R. C., Harley, R. A., Tonse, S., Millet, D. B., Schade, G. W., and Goldstein, A. H.: VOC reactivity in central California: comparing an air quality model to ground-based measurements, Atmos. Chem. Phys., 8, 351-368, doi:10.5194/acp-8351-2008, 2008.

Szidat, S., Jenk, T. M., Gaggeler, H. W., Synal, H. A., Fisseha, R., Baltensperger, U., Kalberer, M., Samburova, V., Reimann, S., Kasper-Giebl, A., and Hajdas, I.: Radiocarbon (C-14)-deduced biogenic and anthropogenic contributions to organic carbon (OC) of urban aerosols from Zurich, Switzerland, Atmos. Environ., 38, 4035-4044, doi:10.1016/j.atmosenv.2004.03.066, 2004.

Thornton, J. A., Wooldridge, P. J., and Cohen, R. C.: Atmospheric NO2: In Situ Laser-Induced Fluorescence Detection at Parts Per Trillion Mixing Ratios, Anal. Chem., 72, 528-539, doi:10.1021/ac9908905, 2000.

Wagner, N. L., Dubé, W. P., Washenfelder, R. A., Young, C. J., Pollack, I. B., Ryerson, T. B., and Brown, S. S.: Diode laser-based cavity ring-down instrument for $\mathrm{NO}_{3}, \mathrm{~N}_{2} \mathrm{O}_{5}, \mathrm{NO}$, $\mathrm{NO}_{2}$ and $\mathrm{O}_{3}$ from aircraft, Atmos. Meas. Tech., 4, 1227-1240, doi:10.5194/amt-4-1227-2011, 2011.

Weber, R. J., Sullivan, A. P., Peltier, R. E., Russell, A., Yan, B., Zheng, M., de Gouw, J., Warneke, C., Brock, C., Holloway, J. 
S., Atlas, E. L., and Edgerton, E.: A study of secondary organic aerosol formation in the anthropogenic-influenced southeastern United States, J. Geophys. Res.-Atmos., 112, D13302, doi:10.1029/2007jd008408, 2007.

Went, F. W.: Blue hazes in the atmosphere, Nature, 187, 641-643, doi:10.1038/187641a0, 1960

Williams, J., Roberts, J. M., Bertman, S. B., Stroud, C. A., Fehsenfeld, F. C., Baumann, K., Buhr, M. P., Knapp, K., Murphy, P. C., Nowick, M., and Williams, E. J.: A method for the airborne measurement of PAN, PPN, and MPAN, J. Geophys. Res.-Atmos., 105, 28943-28960, doi:10.1029/2000jd900373, 2000.

Worton, D. R., Surratt, J. D., LaFranchi, B. W., Chan, A. W. H., Zhao, Y. L., Weber, R. J., Park, J. H., Gilman, J. B., de Gouw, J., Park, C., Schade, G., Beaver, M., St Clair, J. M., Crounse, J., Wennberg, P., Wolfe, G. M., Harrold, S., Thornton, J. A., Farmer, D. K., Docherty, K. S., Cubison, M. J., Jimenez, J. L., Frossard, A. A., Russell, L. M., Kristensen, K., Glasius, M., Mao, J. Q., Ren, X. R., Brune, W., Browne, E. C., Pusede, S. E., Cohen, R. C., Seinfeld, J. H., and Goldsteint, A. H.: Observational Insights into Aerosol Formation from Isoprene, Environ. Sci. Technol., 47, 11403-11413, doi:10.1021/es4011064, 2013.

Worton, D. R., Isaacman, G., Gentner, D. R., Dallmann, T. R., Chan, A. W. H., Ruehl, C., Kirchstetter, T. W., Wilson, K. R., Harley, R. A., and Goldstein, A. H.: Lubricating oil dominates primary organic aerosol emissions from motor vehicles, Environ. Sci. Technol., 48, 3698-3706, doi:10.1021/es405375j, 2014.

Xiao, S., and Bertram, A. K.: Reactive uptake kinetics of $\mathrm{NO}(3)$ on multicomponent and multiphase organic mixtures containing unsaturated and saturated organics, Phys. Chem. Chem. Phys., 13, 6628-6636, doi:10.1039/c0cp02682d, 2011.
Zhang, Q., Jimenez, J. L., Canagaratna, M. R., Allan, J. D., Coe, H., Ulbrich, I., Alfarra, M. R., Takami, A., Middlebrook, A. M., Sun, Y. L., Dzepina, K., Dunlea, E., Docherty, K., DeCarlo, P. F., Salcedo, D., Onasch, T., Jayne, J. T., Miyoshi, T., Shimono, A., Hatakeyama, S., Takegawa, N., Kondo, Y., Schneider, J., Drewnick, F., Borrmann, S., Weimer, S., Demerjian, K., Williams, P., Bower, K., Bahreini, R., Cottrell, L., Griffin, R. J., Rautiainen, J., Sun, J. Y., Zhang, Y. M., and Worsnop, D. R.: Ubiquity and dominance of oxygenated species in organic aerosols in anthropogenically-influenced Northern Hemisphere midlatitudes, Geophys. Res. Lett., 34, L13801, doi:10.1029/2007g1029979, 2007.

Zhang, Y. L., Zotter, P., Perron, N., Prevot, A. S. H., Wacker, L., and Szidat, S.: Fossil and non-fossil sources of different carbonaceous fractions in fine and coarse particles by radiocarbon measurement, Radiocarbon, 55, 1510-1520, doi:10.2458/azu_js_rc.55.16278, 2013.

Zhao, Z. J., Husainy, S., and Smith, G. D.: Kinetics Studies of the Gas-Phase Reactions of NO3 Radicals with Series of 1-Alkenes, Dienes, Cycloalkenes, Alkenols, and Alkenals, J. Phys. Chem. A, 115, 12161-12172, doi:10.1021/jp206899w, 2011a.

Zhao, Z. J., Husainy, S., Stoudemayer, C. T., and Smith, G. D.: Reactive uptake of $\mathrm{NO}(3)$ radicals by unsaturated fatty acid particles, Phys. Chem. Chem. Phys., 13, 17809-17817, doi:10.1039/c1cp21790a, 2011b. 